\title{
A new species of Moenkhausia Eigenmann (Characiformes: Characidae) from the rio Arinos basin, Brazil
}

\author{
Fernando C. P. Dagosta and Manoela M. F. Marinho'
}

A new species of Moenkhausia is described from the rio Arinos drainage, rio Tapajós basin, Mato Grosso, Brazil. The new species is diagnosed from all congeners, except $M$. hemigrammoides, M. nigromarginata, and Moenkhausia rubra by having intense diffuse dark pigmentation on the dorsal and anal fin-rays. The new species can be distinguished from the above mentioned species by the combination of 20-23 branched anal-fin rays, presence of a vertically elongate roughly rectangular humeral spot surpassing the lateral line ventrally, absence of a well-defined black spot on the distal portion of the dorsal fin and lack of a series of longitudinal dark zigzag stripes on body. The new species is herein described along with a report and discussion of a possible connection between the rio Tapajós and rio Paraguay basins, near Diamantino Municipality, Mato Grosso.

Uma espécie nova de Moenkhausia é descrita das drenagens do rio Arinos, bacia do rio Tapajós, Mato Grosso, Brasil. A nova espécie é diagnosticada de todas as congêneres, exceto $M$. hemigrammoides, M. nigromarginata, e Moenkhausia rubra por possuir pigmentação escura intensa e difusa nos raios das nadadeiras dorsal e anal. A nova espécie pode ser distinguida das espécies supracitadas pela combinação da presença de 20-23 raios ramificados na nadadeira anal, presença de uma mancha umeral aproximadamente retangular, ultrapassando a linha lateral ventralmente, ausência de uma mancha negra conspícua na porção distal da nadadeira dorsal e pela ausência de uma série de linhas longitudinais negras em forma de zigue-zague no corpo. A nova espécie é aqui descrita, juntamente com o relato de uma possível conexão entre as bacias dos rios Tapajós e rio Paraguay, próximo ao município de Diamantino, Mato Grosso.

Keywords: Headwaters, Juruena, Moenkhausia nigromarginata, Moenkhausia rubra, Tapajós.

\section{Introduction}

Moenkhausia Eigenmann currently includes about 80 valid species (Eschmeyer, 2016) widely distributed in South American freshwaters. It is a Characidae genus defined by a combination of the presence of teeth arranged in two rows in the premaxilla, with five teeth in the inner row, lateral line complete, and small scales partially covering the caudal-fin lobes (Eigenmann, 1903, 1917). None of these characters are unique for the genus and all are known to be highly homoplastic within the Characidae (Mirande, 2010). Therefore, the delimitation of Moenkhausia based on such character combination is very likely artificial.

The genus comprises species with a broad variety of body forms and coloration patterns. For example, species of the "Moenkhausia oligolepis/M. sanctaefilomenaespecies complex" (Costa, 1994; Lima \& Toledo-Piza, 2001; Lima et al., 2007; Benine et al., 2009) have a characteristic reticulated color pattern on body, red eye and a light area followed by a large dark caudal-peduncle blotch, Moenkhausia browni Eigenmann, M. comma Eigenmann, and $M$. levidorsa Benine are relatively large species with deep body, M. ceros Eigenmann, M. collettii Steindachner and M. lopesi Britski \& de Silimon are small and shallow-bodied forms as well as Moenkhausia bonita Benine, Castro \& Sabino and M. hemigrammoides Géry, which are Hemigrammus-like species very similar to $H$. marginatus Ellis and $H$. unilineatus Gill, respectively, and M. agnesae Géry and Moenkhausia cosmops Lima, Britski \& Machado, with colorful bodies, appreciated as ornamental species.

A recent examination of the species of Moenkhausia deposited in the Museu de Zoologia da Universidade de São Paulo revealed specimens of a undescribed species from the rio Arinos drainage, rio Tapajós basin. The undescribed species have dark fins, similar to M. nigromarginata Costa and M. rubra Pastana \& Dagosta. Additional material

Museu de Zoologia da Universidade de São Paulo, Avenida Nazaré, 481, Ipiranga, 04263-000 São Paulo, SP, Brazil.

(FCPD) ferdagosta@gmail.com (corresponding author), (MMFM) manumfm@yahoo.com.br 
from the species was later located at Museu de Ciências e Tecnologia da Pontifícia Universidade Católica do Rio Grande do Sul and ZUEC. For color in life description, an expedition to the rio Arinos in the surroundings of Nova Mutum, Mato Grosso was performed. The new species is herein described along with a report and discussion of a possible connection between the rio Tapajós and rio Paraguay basins.

\section{Material and Methods}

Morphometric and meristic data follow Fink \& Weitzman (1974), except for number of horizontal scale rows below lateral line, counted to the pelvic-fin origin, and with the addition of head depth, measured at vertical through the posteriormost tip of supraoccipital spine. Standard length (SL) is given in millimeters, subunits of body are expressed as percentage of SL, and subunits of head as percentage of head length (HL). In the description, the frequency of each count is provided in parentheses after the respective count, with the count of the holotype indicated by an asterisk. Counts of maxillary tooth cusps, posterior small dentary teeth, supraneurals, branchiostegal rays, gill rakers, vertebrae, unbranched anal-fin rays and procurrent caudal-fin rays are obtained from cleared and stained specimens (c\&s) prepared according to Taylor \& Van Dyke (1985). Vertebrae of the Weberian apparatus are counted as four elements and the compound caudal centra (PU1+U1) as one element. The sex of five specimens was confirmed by dissection. In the list of type and comparative material, catalog numbers are followed by the number of specimens in alcohol, their SL range, measured and counted specimens and their SL range in parenthesis, and if any, the number of c\&s specimens with their SL range. Institutional abbreviations follow Ferraris Jr. (2007). Figure 3 was produced with the aid of Google Earth (Google Inc.) and Quantum GIS (Geographic Information System - Open Source Geospatial Foundation Project) software in association with geographic maps of IBGE (Instituto Brasileiro de Geografia e Estatística).

\section{Results}

\section{Moenkhausia mutum, new species}

urn:1sid:zoobank.org:act:BB985C10-AFC9-4130-BDFD91679686FD7F

\section{Fig. 1 and Table 1}

Holotype. MZUSP 117071, 65.3 mm SL, Brazil, Mato Groso State, Nova Mutum, stream at road Nobres-Nova Mutum, on the intersection before Nova Mutum, tributary of rio dos Patos, rio Arinos drainage, rio Tapajós basin, 1349'9'S 56¹0'53.9'W, F. Dagosta, W. Ohara \& V. Giovannetti, 14 Nov 2014.
Paratypes. All from Brazil, Mato Grosso, rio Arinos, upper rio Tapajós basin. MCP 31997, 4, 36.0-47.9 mm SL (3, 44.947.9 mm SL), MCP 32005, 1, 61.8 mm SL (1), Diamantino, córrego Caju, at Caju locality, tributary of the rio Preto, 14'21'47"S 56²4'30"W, R. E. Reis, L. R. Malabarba \& N. E. Pereira, 17 Jan 2002. MCP 32057, 1, $54.1 \mathrm{~mm}$ SL (1), Porto dos Gaúchos, igarapé Ribeirão Preto at MT-338 road, about

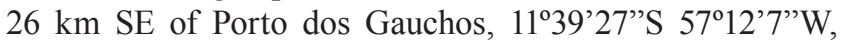
R. E. Reis, L. R. Malabarba \& N. E. Pereira, 19 Jan 2002. MCP 32098, 2, 35.0-42.1 mm SL (2), São José do Rio Claro, córrego about $4 \mathrm{~km} \mathrm{NW}$ of São José do Rio Claro, at road to Nova Maringá, $13^{\circ} 25^{\prime} 51^{\prime \prime} \mathrm{S} 56^{\circ} 44^{\prime} 53^{\prime \prime W}, \mathrm{R}$. E. Reis, L. R. Malabarba \& N. E. Pereira, 18 Jan 2002. MCP 32171, 1, $38.1 \mathrm{~mm}$ SL (1), Tapurah, córrego at MT-338 road, about 46 km N of Tapurah, 12²3'14"S 56 $41^{\circ} 54^{\prime \prime} W$, R. E. Reis, R. L. Malabarba \& E. H. Pereira, 19 Jan 2002. MCP 44446, 1, $35.3 \mathrm{~mm}$ SL, Nova Mutum, rio Criquiri, about $8 \mathrm{~km}$ of Nova Mutum, 1348'11'S 56²'23'W, F. Jerep, 24 Jan 2009. MZUSP 61094, 44, 25.2-43.2 mm SL (1, $42.1 \mathrm{~mm}$ SL), Nova Mutum, rio Criquiri, tributary of Rio dos Patos, 13\%48'10' $S$ 5609'29''W, F. C. T. Lima, M. R. Britto, W. B. Wosiacki, P. Gerhard, \& E. G. Baena, 19 Fev 2000. MZUSP 61119, 31, 26.3-50.4 mm SL (5, 45.2-50.4 mm SL), Nova Mutum, rio Criquiri, tributary of rio dos Patos, F. C. T. Lima, M. R. Britto, W. B. Wosiacki, P. Gerhard, \& E. G. Baena, 1350'60" S 56¹0'60'W, 16 Feb 2000. MZUSP 117072, 21, 40.0-60.9 mm SL, (14, 51.1-60.9 mm SL), 3 c\&s, 37.2-50.0 mm SL, CAS 238019, 5, 49.5-54.9 mm SL, same data as holotype. ZUEC 10059, 6, 52.7-56.8 mm SL (1, 58.5 mm SL), São José do rio Claro, rio Claro, upstream to the bridge at the MT$235 \mathrm{road}, 13^{\circ} 53$ '30'S 56²1'01'W, I. M. Fernandes \& G. M. Alencar, 4-5 May 2007.

Diagnosis. Moenkhausia mutum is distinguished from all congeners, except $M$. hemigrammoides, $M$. nigromarginata and Moenkhausia rubra by having intense diffuse dark pigmentation on the dorsal and anal fin-rays, especially in anteriormost rays and in the distal portion ( $v s$. fins hyaliane or only with scattered chromatophores). It can be distinguished from $M$. rubra by the number of branched anal-fin rays 20-23, modally 21 (vs. 17-20, modally 19) and by having a vertically elongate humeral spot ( $v s$. approximately rounded), from $M$. hemigrammoides by having pelvic fin intensely dark pigmentated ( $v s$. hyaline), by the anal fin with a relative diffuse dark pigmentation ( $v s$. presence of a black oblique line extending from the urogenital cavity to the tip of second or third branched anal-fin ray), and by lacking a well-defined black spot on the distal portion of the dorsal fin (vs. present), and from $M$. nigromarginata by lacking a series of longitudinal dark zigzag stripes on body formed by the concentration of dark chromatophores in the upper and lower portions of the exposed area of scales ( $v s$. presence) and by having a vertically elongate roughly rectangular humeral spot surpassing the lateral line ventrally ( $v s$. humeral spot approximately rounded, with an anteroventral projection not surpassing the lateral line ventrally). 

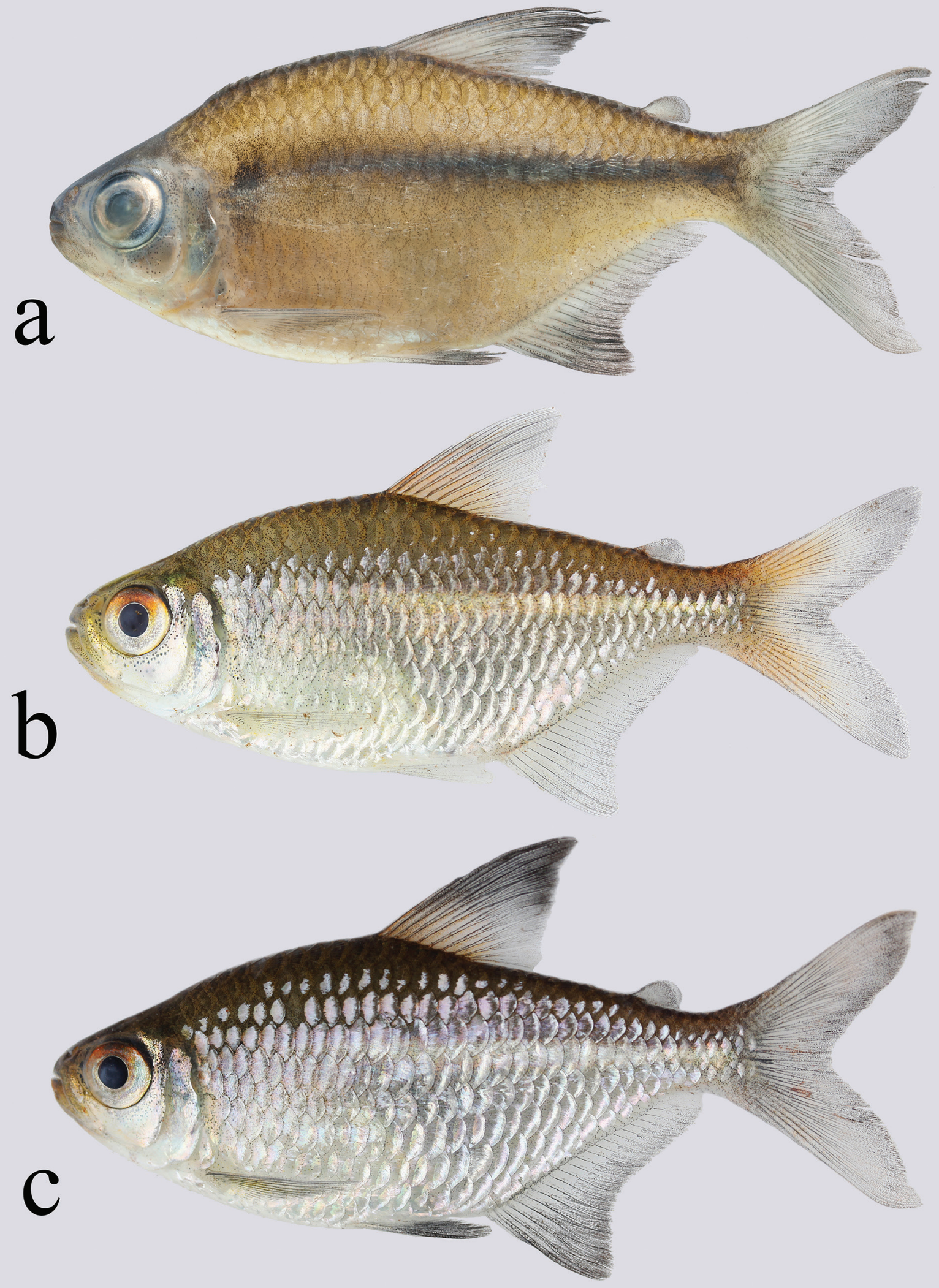

Fig. 1. Moenkhausia mutum, new species, Brazil, Mato Grosso, Nova Mutum, rio Arinos drainage, rio Tapajós basin: (a) holotype alcohol preserved, MZUSP 117071, $65.3 \mathrm{~mm} \mathrm{SL}$, (b) paratype, live coloration, MZUSP 117072, $53.6 \mathrm{~mm}$ SL, collected with the holotype, (c) holotype, live coloration. 
Description. Morphometric data presented in Table 1. Body compressed, moderately deep. Greatest body depth slightly anterior to dorsal-fin origin. Dorsal profile of head convex from upper lip to vertical through posterior nostril and slightly convex from that point to tip of supraoccipital spine. Dorsal profile of body convex along predorsal region, straight along dorsal-fin base, straight or slightly convex from terminus of dorsal-fin base to adipose-fin origin, and concave from the latter point to origin of anteriormost dorsal procurrent caudal-fin ray. Ventral profile of head and body convex from tip of lower lip to pelvic-fin origin, slightly concave from that point to anal-fin origin, straight along anal-fin base, and concave from that point to origin of anteriormost ventral procurrent caudal-fin ray.

Jaws equal, mouth terminal. Premaxillary teeth in two distinct rows. Outer row with $3(5), 4 *(17)$ or 5(8) tricuspid teeth. Inner row with $5^{*}(30)$ pentacuspid teeth. Posterior tip of maxilla at vertical through middle of second infraorbital. Maxilla with 1(1), 2*(17) or 3(12) tricuspid teeth. Dentary with $4 *(30)$ larger penta- to heptacuspid teeth followed by a series of 9(1) or 10(2) diminute conical teeth. Central median cusp in all teeth longer than lateral cusps. Branchiostegal rays 4(3). First gill arch with 2(2) or 3(1) gill rakers on hypobranchial, 8(3) rakers on ceratobranchial, 1(3) raker on intermediate cartilage, and 6(2) or 7(1) rakers on epibranchial.
Eyes with thick eyelid anteriorly. Scales cycloid, with 5-9 strongly marked radii from focus to posterior border, and conspicuous circuli anteriorly. Lateral line complete, with $31(1), 32(10), 33(11), 34 *(7)$ or 35(1) perforated scales on longitudinal series. Longitudinal scale rows between dorsal-fin origin and lateral line $5^{*}(29)$ or $6(1)$. Longitudinal scale rows between lateral line and pelvic-fin origin 3(5) or $4 *(25)$. Scales along middorsal line between posterior tip of supraoccipital process and dorsal-fin origin $8(7), 9 *(19)$ or 10(4). Horizontal scale rows around caudal peduncle 13(1) or 14(29). Base of anteriormost anal-fin rays covered by a series of 3-5 scales. Proximal half of caudal-fin lobes covered by small scales.

Supraneurals 3(1) or 4(2). Dorsal-fin rays ii*(30), 8(1) or 9(29). First dorsal-fin pterygiophore inserted posterior to neural spine of ninth(3) vertebra. Base of last dorsal-fin ray at vertical through base of first branched anal-fin ray. Pectoral-fin rays $i^{*}(30), 11(9), 12 *(20)$ or $13(1)$. Pelvic-fin rays $i^{*}(30), 7^{*}(30)$. Adipose fin present. Anal-fin falcate, with iv(1) or v(2), 20(3), 21*(12), 22(11) or 23(4) rays. First anal-fin pterygiophore inserted posterior to haemal spine of $16^{\text {th }}(3)$ vertebra. Principal caudal-fin rays i,9,8,i*(30). Caudal fin forked, lobes somewhat pointed, of similar size. Dorsal procurrent caudal-fin rays 11(2) or 12(1). Ventral procurrent caudal-fin rays $8(1)$ or 9(2). Total vertebrae $32(2)$ or 33(1): precaudal vertebrae 16(3) and caudal vertebrae 16(2) or 17(1).

Table 1. Morphometric data of Moenkhausia mutum. Range of paratypes includes the holotype. SD = Standard deviation, $\mathrm{n}=$ number of observations.

\begin{tabular}{|c|c|c|c|c|c|}
\hline & Holotype & $\mathrm{n}$ & Paratypes & Mean & $\mathrm{SD}$ \\
\hline Standard Length $(\mathrm{mm})$ & 65.3 & 30 & $34.5-65.3$ & 51.1 & \\
\hline \multicolumn{6}{|c|}{ Percents of SL } \\
\hline Depth at dorsal-fin origin & 44.9 & 30 & $36.2-46.4$ & 41.4 & 2.6 \\
\hline Snout to dorsal-fin origin & 52.9 & 30 & $49.3-53.4$ & 51.4 & 1.1 \\
\hline Snout to pectoral-fin origin & 28.2 & 30 & $26.1-29.8$ & 27.9 & 0.9 \\
\hline Snout to pelvic-fin origin & 48.1 & 30 & $47.2-53.1$ & 49.7 & 1.3 \\
\hline Snout to anal-fin origin & 65.6 & 30 & $64.8-70.3$ & 67.1 & 1.5 \\
\hline Caudal-peduncle depth & 12.5 & 30 & $9.8-19.7$ & 11.3 & 1.7 \\
\hline Caudal-peduncle length & 10.5 & 30 & $9.8-12.5$ & 10.8 & 0.6 \\
\hline Pectoral-fin length & 25.4 & 30 & $22.3-25.5$ & 24.1 & 0.9 \\
\hline Pelvic-fin length & 21.2 & 30 & $17.8-22.0$ & 19.6 & 1.1 \\
\hline Pelvic-fin origin to anal-fin origin & 19.5 & 30 & $17.1-21.4$ & 19.4 & 1.0 \\
\hline Dorsal-fin length & 33.9 & 30 & $28.3-33.9$ & 31.2 & 1.2 \\
\hline Dorsal-fin base length & 15.6 & 30 & $14.1-16.6$ & 15.3 & 0.7 \\
\hline Anal-fin length & 21.4 & 30 & $18.7-24.2$ & 21.3 & 1.4 \\
\hline Anal-fin base length & 30.4 & 30 & $25.8-31.9$ & 29.6 & 1.2 \\
\hline Eye to dorsal-fin origin & 39.2 & 30 & $34.5-39.4$ & 37.1 & 1.4 \\
\hline Dorsal-fin origin to caudal-fin base & 54.0 & 30 & $51.3-56.1$ & 53.8 & 1.1 \\
\hline Head depth & 33.8 & 30 & $27.7-34.5$ & 30.8 & 1.6 \\
\hline Head length & 26.4 & 30 & $24.9-29.4$ & 26.5 & 1.1 \\
\hline \multicolumn{6}{|c|}{ Percents of HL } \\
\hline Horizontal eye diameter & 44.1 & 30 & $40.5-48.1$ & 44.7 & 2.0 \\
\hline Snout length & 28.6 & 30 & $22.8-28.6$ & 26.0 & 1.2 \\
\hline Interorbital width & 35.5 & 30 & $32.2-38.0$ & 35.2 & 1.6 \\
\hline Upper jaw length & 46.6 & 30 & $44.0-49.4$ & 46.7 & 1.5 \\
\hline
\end{tabular}


Color in alcohol. Overall ground coloration of head and body beige to light tan (Fig. 1). Some specimens retaining guanine on infraorbital and opercular area and in some scales in the lateral portion of body. Dorsal portion of head and body dark. Dark chromatophores concentrated at upper and lower jaws. Scattered dark pigmentation more concentrated on first, fifth and sixth infraorbitals. Humeral blotch roughly rectangular and vertically oriented, overlying three or four scales vertically including the lateral line scale and three scales horizontally. Slight reticulated pattern on first three horizontal scale rows formed by concentration of dark chromatophores at the middle portions of scales. Scales of body with dark chromatophores concentrated at their posterior limit, more intense at the mid-dorsal scales. Overall body with scattered dark chromatophores gradually fading ventrally. A thin longitudinal line formed by subjacent dark pigmentation along horizontal septum starting slightly posterior to humeral blotch, extending onto caudal peduncle. Longitudinal dark stripe on body approximately one scale wide, extending from vertical through dorsal-fin origin to caudal peduncle, widening at caudal peduncle in some specimens, but not forming a peduncle-caudal spot. Caudalpeduncle spot absent. Scattered dark chromatophores along base of anal fin. Pectoral fin with dark chromatophores scattered along edge of lepidotrichia. Proximal half of dorsal, anal, and caudal fins with scattered dark chromatophores along edge of lepidotrichia. Distal half of dorsal, anal, and caudal fins with high concentration of dark chromatophores at interradial membranes, more intense in anteriormost dorsal and anal fin-rays. Some specimens with distalmost pelvic-fin rays with scattered dark chromatophores along edge of lepidotrichia and interradial membranes. Adiposefin base with scattered dark chromatophores, distal edge with intense dark pigmentation.

Color in life. Jaws and gular area orange. Dorsal portion of eye red in most specimens, brown in others. Lower portion of eye silvery. Dorsal portion of body dark brown. Infraorbitals, opercular area, middorsal and ventral portions of body silvery. Proximal half of dorsal fin orange. Some specimens with base of caudal-fin lobes orange. Dark pigmentation pattern of fins as described in Color in alcohol.

Sexual dimorphism. One male specimen (MZUSP 117072, $50.0 \mathrm{~mm} \mathrm{SL}$ ) presents very small bony hooks at the first to the thirteenth branched anal-fin ray, more developed in anteriormost ones. Hooks more concentrated at the posterior edge of the lepidotrichia.

Geographic distribution. Moenkhausia mutum is known from the rio Arinos drainage, tributary of rio Juruena, upper rio Tapajós basin, Mato Grosso State, Brazil (Fig. 2).

Etymology. The specific name mutum is in allusion to the Brazilian popular name of the curassow birds of the genus Crax Linnaeus, which are typically dark colored, as well as the fins of Moenkhausia mutum. Also, the name refers to the Nova Mutum Municipality, the type locality, and where most of the type specimens were collected. A name in apposition.

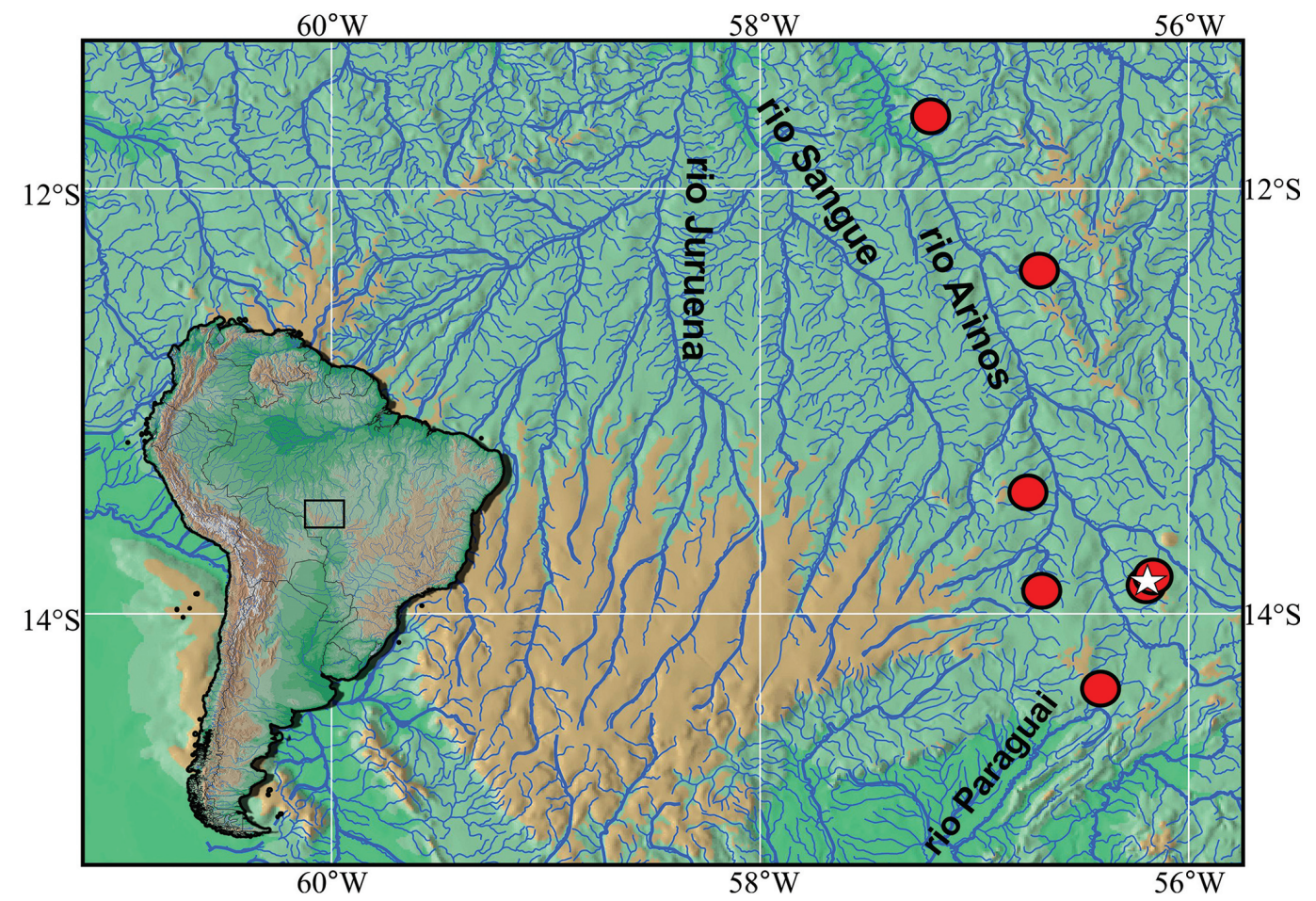

Fig. 2. Distribution map of Moenkhausia mutum in the upper rio Tapajós basin, Amazon basin. Type locality represented by white star. 
Conservation status. Moenkhausia mutum is so far known from the rio Arinos drainage, the major tributary of rio Juruena, rio Tapajós basin, where it is widely distributed. Despite existing some riparian forest degradation for pasture in several sites where $M$. mutum occurs, it seems to not preclude the presence of the species in these areas. Therefore, Moenkhausia mutum would be classified as Least Concern (LC) following the International Union for Conservation of Nature (IUCN) categories and criteria (IUCN Standards and Petitions Subcommittee, 2014).

\section{Discussion}

A notable condition present in Moenkhausia mutum is the concentration of dark chromatophores at the distal portions of pelvic, dorsal, and anal fins. Among its congeners, this feature is solely present in $M$. nigromarginata and M. rubra, species also from the upper rio Tapajós basin. The shared presence of such unique color pattern among these species of Moenkhausia along with the similar overall body morphology may indicate that they are closely related. However, phylogenetic studies including these and other species currently assigned to Moenkhausia and related genera are necessary to a proper understanding of the phylogenetic significance of these characters.

It is important to mention two specimens of a putative undescribed species (ZUEC 6352, MZUSP 106156) from the rio Manso (rio Paraguay basin), which shares a similar pigmentation pattern on fins and overall body morphology with the new species. Nevertheless, these specimens lack humeral spot and have more branched anal-fin rays (24 vs. 20-23 in Moenkhausia mutum) and therefore were herein considered as representing a distinct species.

Two lots of Moenkhausia mutum (MCP 31997 and MCP 32005) were collected at the córrego Caju which, along with córrego Mata Grande and córrego Cedro (Fig. 3), forms the headwaters of the rio Preto, a tributary of the rio Arinos (rio Tapajós basin, Amazon basin). It is noteworthy the great proximity between the headwaters of the córrego Mata Grande (rio Arinos basin) and córrego Macaco (rio Paraguay basin) (Fig. 3). These headwaters are close to such extent, about few ten meters in a relatively flat relief, that it is difficult to precise for sure whether these basins were connected or not before the construction of the BR364 road (dashed line in Fig. 3), which today separates their headwaters. Further remarkable features of these headwaters are the longitudinal alignment between the córrego Macaco (rio Paraguay basin) and córrego Mato Grande (rio Tapajós basin) and the unusual shape of the córrego Macaco, with an acute angle of nearly $90^{\circ}$ (yellow arrow in Fig. 3), which, together, may be geologically meaningful. Acute angles in water bodies may indicate a stream capture (Bishop, 1995; Pederson, 2001; Bharatdwaj, 2006; Pastor et al., 2012). It can be defined as the point where the course of a captured stream has been diverted to the course of the captor stream (Bharatdwaj, 2006). A detailed ichthyofaunal inventory in the area would be helpful in the pursuit of shared species, towards an independent confirmation of such geological event in the region.

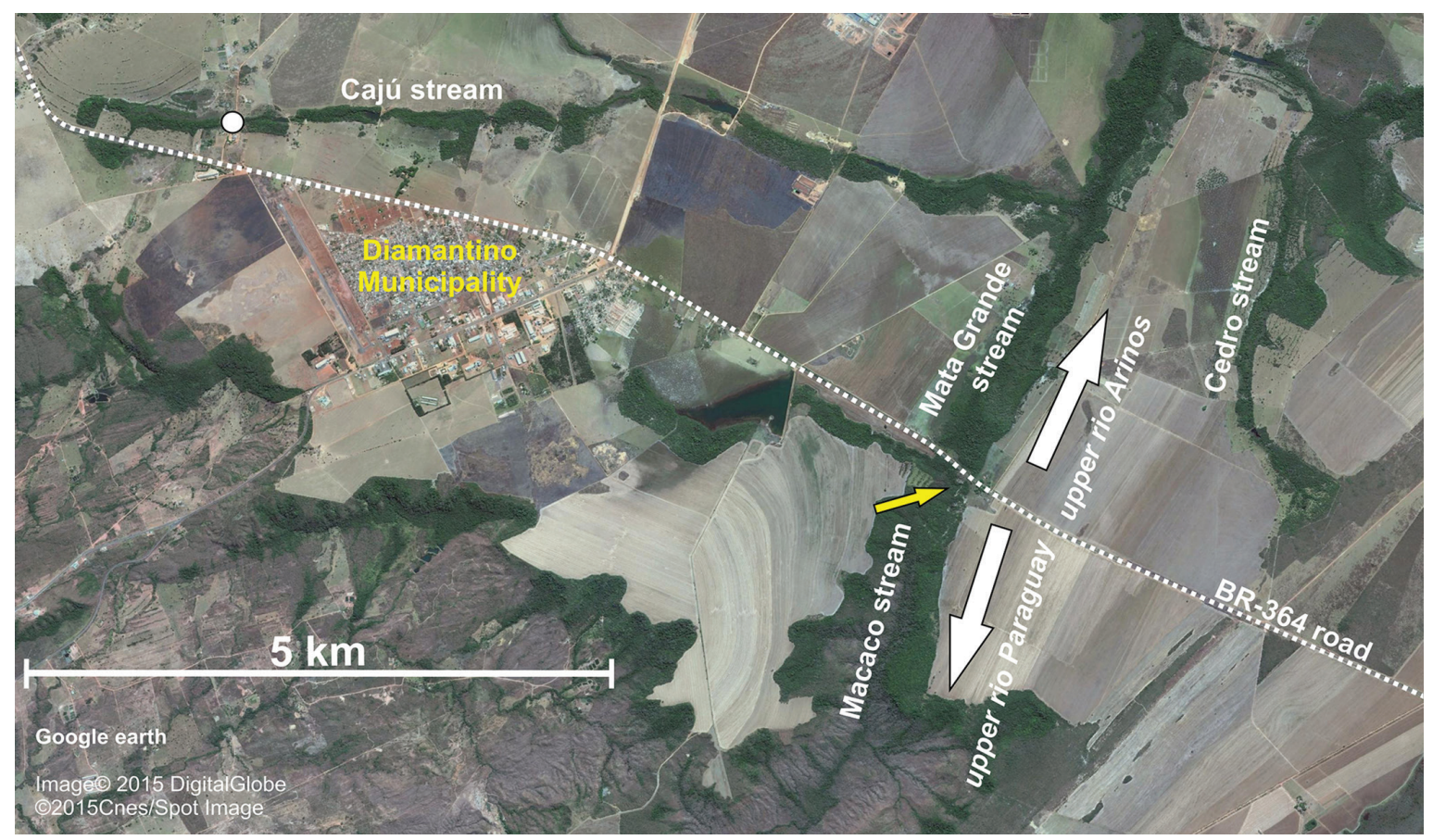

Fig. 3. Detail from the region of Diamantino Municipality, Mato Grosso State: dashed line represents BR-364, which separates the headwaters of rio Tapajós (córrego rio Preto and tributaries) and rio Paraguay basin (córrego Macaco). Yellow arrow represents the acute angle of the córrego Macaco. 
Comparative material examined. All from Brazil: Moenkhausia sp.: rio Paraguay basin: MZUSP 106156, 1, $42.3 \mathrm{~mm}$ SL, Mato Grosso. ZUEC 6352, 1, 37.7 mm SL, Mato Grosso. Moenkhausia aurantia: rio Tocantins basin: MZUSP 107827, 8, 27.7- 40.0 mm SL, paratypes of Moenkhausia aurantia Bertaco, Jerep \& Carvalho, 2011, Goiás. MZUSP 113835, 25, 33.0-49.5 mm SL, Goiás. Moenkhausia hemigrammoides: rio Negro basin: MZUSP 92294, 84, 29.2-30.7 mm SL, MZUSP 92501, 10, 27.0-32.7 mm SL, Amazonas. Moenkhausia nigromarginata: rio Papagaio basin: MZUSP 45289, 1, $40.1 \mathrm{~mm}$ SL, paratype of Moenkhausia nigromarginata Costa, 1994, MZUSP 93509, 156, 24.1-49.0 mm SL, Mato Grosso. Moenkhausia rubra: rio Juruena basin: LIRP 7657, 1, $31.1 \mathrm{~mm}$ SL, paratype of Moenkhausia rubra Pastana \& Dagosta, 2014, LIRP 8164, 8, 36.5-54.3 mm SL, paratypes Moenkhausia rubra Pastana \& Dagosta, 2014, LIRP 8177, 6, 37.1$47.2 \mathrm{~mm}$ SL, 1 c\&s, $45.8 \mathrm{~mm}$ SL, paratypes Moenkhausia rubra Pastana \& Dagosta, 2014, MZUSP 114032, 1, 39.8 mm SL, paratype Moenkhausia rubra Pastana \& Dagosta, 2014, Mato Grosso.

\section{Acknowledgements}

Willian Ohara and Vitor Giovanetti for helping in the field and in figures $1 \mathrm{~b}$ and c. Flávio Lima for discussing the similarity of the undescribed species (MZUSP 106156, ZUEC 6352). Part of the specimens was collected during an expedition funded by the South American Characiformes Inventory (FAPESP 2011/50282-7, http://www.projetosaci.com). Visit to the MCP fish collection by MMFM was funded by "Projeto qualificação taxonômica da base de dados da coleção de peixes do MCT-PUCRS para uso on-line" (MCT/CNPq). Authors were funded by FAPESP (FCPD: 2011/23419-1; MMFM: 2014/11911-7).

\section{References}

Benine, R. C., T. C. Mariguela \& C. Oliveira. 2009. New species of Moenkhausia Eigenmann, 1903 (Characiformes: Characidae) with comments on the Moenkhausia oligolepis species complex. Neotropical Ichthyology, 7: 161-168.

Bharatdwaj, K. 2006. Physical Geography: Hydrosphere. New Delhi, Discovery Publishing House, 356p.

Bishop, P. 1995. Drainage rearrangement by river capture, beheading, and diversion. Progress in Physical Geography, 19: 449-473.

Costa, W. J. E. M. 1994. Description of two new species of the genus Moenkhausia (Characiformes: Characidae) from the central Brazil. Zoologischer Anzeiger, 232: 21-29.
Eigenmann, C. H. 1903. New genera of South American freshwater fishes, and new names for old genera. Smithsonian Miscellaneous Collections 45: 144-148.

Eigenmann, C. H. 1917. The American Characidae. Part I. Memoirs of the Museum of Comparative Zoology, 43: 1-102.

Eschmeyer, W. N. 2016. Catalog of fishes: genera, species, references. Available from: http://researcharchive. calacademy.org/research/ichthyology/catalog/fishcatmain. asp. (1 April 2016).

Ferraris Jr., C. J. 2007. Checklist of catfishes, recent and fossil (Osteichthyes: Siluriformes), and catalogue of siluriform primary types. Zootaxa, 1418: 1-628.

Fink, W. L. \& S. H. Weitzman. 1974. The so-called cheirodontin fishes of Central America with descriptions of two new species (Pisces: Characidae). Smithsonian Contributions to Zoology, 172: 1-46.

IUCN Standards and Petitions Subcommittee. 2014. Guidelines for using the IUCN Red List Categories and Criteria. Version 11. Prepared by the Standards and Petitions Subcommittee. Available from http:/www.iucnredlist.org/documents/ RedListGuidelines.pdf. (28 April 2015).

Lima, F. C. T., H. A. Britski \& F. A. Machado. 2007. A new Moenkhausia (Characiformes: Characidae) from central Brazil, with comments on the area relationship between the upper rio Tapajós and upper rio Paraguai systems. Aqua International Journal of Ichthyology, 13: 45-54.

Lima, F. C. T. \& M. Toledo-Piza. 2001. New species of Moenkhausia (Characiformes: Characidae) from the rio Negro of Brazil. Copeia, 2001(4): 1058-1063.

Mirande, J. M. 2010. Phylogeny of the family Characidae (Teleostei: Characiformes): from characters to taxonomy. Neotropical Ichthyology, 8: 385-568.

Pastor, A., J. Babault, A. Teixell \& M. L. Arboleya. 2012. Intrinsic stream-capture control of stepped fan pediments in the High Atlas piedmont of Ouarzazate (Morocco). Geomorphology, 173-174: 88-103.

Pederson, D. T. 2001. Stream piracy revisited: a groundwatersapping solution. Geological Society of America - GSA Today, 9: 4-10.

Taylor, W. R. \& G. C. Van Dyke. 1985. Revised procedures for staining and clearing small fishes and other vertebrates for bone and cartilage study. Cybium, 9: 107-119.

Submitted April 28, 2015 Accepted March 27, 2016 by Lilian Casatti 